\title{
Photographic image tissue characterization of the ulcerated diabetic foot during treatment: technical note
}

\author{
Caracterização tecidual de imagem fotográfica durante \\ tratamento do pé diabético ulcerado: nota técnica \\ Vitor Hugo Honorato Pereira', Edelson Moreira da Costa Filho', Fernanda Thaysa Avelino dos Santos', \\ Thays Fernanda Avelino dos Santos', Sergio Xavier Salles Cunha², Kaique Alves de Melo Brandino, \\ Rafaella Alves da Silva Barbosa', Jackson Silveira Caiafa ${ }^{4}$
}

\begin{abstract}
Treatment of an ulcerated diabetic foot was documented photographically. We adapted the ultrasonographic tissue characterization (USTC or CATUS) technique to develop a photographic image tissue characterization (p-IMTC or CATIM) method. Five photographs, taken during medical treatment of an ulcerated diabetic foot following digital amputation, were quantified using imaging software designed to determine brightness intensity in grey scale images. The grey scale median (GSM) changed from 127 to 98; 86; 76; and 83 (out of 255) during follow-up. The area of lesion was estimated by number of pixels and reduced from $17.85 \mathrm{~cm}^{2}$ to $12.44 ; 3.68 ; 2.11$; and $0.15 \mathrm{~cm}^{2}$. The percentage of total number of pixels showing granulation tissue increased from $11 \%$ to $34 \% ; 56 \% ; 62 \%$; and $75 \%$. p-IMTC quantified treatment progress. GSM quantified generalized changes in tissues, while the area of lesion and granulation tissue were documented quantitatively. Lesions, ulcers, wounds or other tissues can be analyzed using p-IMTC, allowing quantification, characterization and control of the progression of a condition or treatment.
\end{abstract}

Keywords: diabetic foot; ulcer; photography; quantitative analysis.

\begin{abstract}
Resumo
Tratamento do pé diabético ulcerado é documentado fotograficamente. Adaptamos a técnica da caracterização tecidual ultrassonográfica (CATUS ou USTC) para análise da imagem fotográfica (CATIM ou p-IMTC). Cinco fotografias obtidas durante tratamento médico de pé diabético ulcerado, pós-amputação digital, foram quantificadas por software de imagem desenvolvido para caracterizar amplitudes de brilho em tons cinza. A mediana da escala cinzenta, ou Grey Scale Median (GSM), alterou de 127 para 98; 86; 76; e 83 durante o seguimento. Área da lesão, estimada por número de pixels, diminuiu de 17,85 para 12,44; 3,68; 2,11; e 0,15 cm². A porcentagem de número de pixels com granulação aumentou de $11 \%$ para 34\%; 56\%; 62\%; e 75\%. CATIM quantificou progresso do tratamento. GSM quantificou modificações generalizadas do tecido, a área da lesão foi estimada e a granulação foi documentada quantitativamente. Análises CATIM de lesões, úlceras, feridas, ou outros tecidos podem ser feitas, permitindo quantificação, caracterização e controle da evolução do agravo ou tratamento.
\end{abstract}

Palavras-chave: pé diabético; úlcera; fotografia; análise quantitativa.

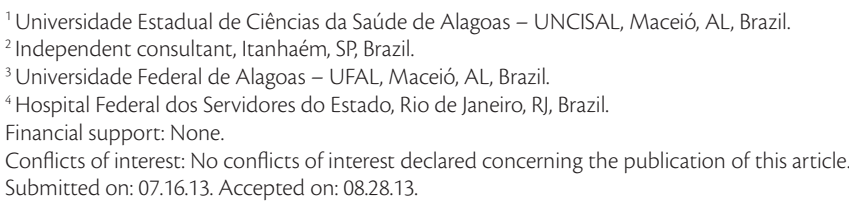




\section{INTRODUCTION}

The diabetic foot, especially the ulcerated diabetic foot, continues to be a challenge for modern medicine ${ }^{1}$. One major consequence is amputations, ranging from removal of toes to leg amputations above or below the knee ${ }^{2}$. Photography has been used to document treatment of ulcerated diabetic feet. One measure commonly used is area of the lesion ${ }^{3}$. We investigated the utility of photographic tissue analysis as a supplementary, quantitative option.

This paper describes the process of adapting ultrasonographic tissue characterization (USTC or CATUS) and ultrasound virtual histology (USVH) processes to achieve photographic image tissue characterization (p-IMTC or CATIM). The primary objective was to determine whether the p-IMTC technique based on the photographic brightness of different tissues would be capable of describing the healing process both qualitative and quantitatively. Future objectives are to a) forecast healing time and likelihood of treatment success and b) identify quantitative criteria for changing treatment. This initial step is a "discovery" process, opening up new technological options.

Transcutaneous methods have already been employed to analyze abdominal aneurysms treated with endoprostheses ${ }^{4}$, kidneys ${ }^{5,6}$, carotid and peripheral atheromas ${ }^{7-10}$, venous thrombosis ${ }^{11-13}$ and edema, in particular, lymphedema ${ }^{14}$. USTC or CATUS is a variant of IVUS. The literature contains reports of correlations between IVUS and histological findings for coronary and carotid atheromas ${ }^{7,15,16}$. Grey scale median (GSM) is a practical simplification representing overall echogenicity. Low GSM correlated with an unacceptable high rate of cerebral vascular accidents during stenting of the carotid artery ${ }^{9}$. GSM was also related to ease of reentry during treatment of occlusive femoral atherosclerosis by subintimal angioplasty ${ }^{8}$. A study assessing lower extremity deep vein thrombosis showed distinctive ultrasonographic echoes and specific GSM values with either high positive predictive value, or high sensitivity to differentiate acute from subacute thrombi ${ }^{12}$. We describe in this paper the application of p-IMTC to five photographs taken during treatment of an ulcerated diabetic foot post hallux amputation.

\section{CASE DESCRIPTION}

The patient was a 48-year-old male who had been diagnosed with diabetes mellitus in 1996 and had been treated with oral hypoglycemic drugs and insulin. He had attenuated distal pulses and no sensitivity to the monofilament test in either foot, but with perfusion preserved. The patient was a smoker and admitted to mild alcoholism. He was seen at the emergency department. The patient presented with a gangrenous left hallux, developed after a trauma caused by dropping an object onto his great toe. The wound became infected and did not respond to the antibiotics prescribed by the treating physician. The toe became gangrenous and the infection was progressing to the dorsum of the foot. The hallux was amputated, the left foot debrided and the abscess was drained. The patient was given fibrous calcium alginate during the first postoperative day. ColStimulen ${ }^{\mathrm{TM}}$ collagen gel was applied. The patient responded well to treatment with satisfactory granulation and healing of the lesion; 95\% of the wound underwent epithelialization within 3 months.

\section{Photographic image tissue characterization (p-IMTC)}

Five photographic images were taken during the period of non-surgical medical treatment and healing. The p-IMTC technique classified the pixels based on the brightness amplitude of grey scale versions of the photographic images. The steps involved in image analysis were as follows:

- 1.Selection of color photographs of the patient's foot (Figure 1 - column 1);

- 2.Conversion of color images into 256-tone grey scale images, where black equals 0 and white equals 255 (Figure 1 - column 2);

- 3.Minimization of variations by rescaling using black and the pseudo white of the $1 \mathrm{~cm}$ tag placed near the wound as the new 0 and 200 brightness levels, respectively;

- 4.Selection of area for analysis (Figure 1 - column 2);

- 5.Presentation of pixel brightness distribution in the image and GSM calculation (Figure 1 - column 3);

- 6.Calculation of percentages of number of pixels into 14 intervals of brightness amplitudes and presentation as histograms (Figure 1 - column 4);

- 7.Artificial colorization of pixels in the selected region of the image based on the 14 intervals of brightness amplitudes (Figure 1 - column 5);

- 8.Calculation of wound area based on number of pixels in the a) wound region and b) $1 \mathrm{~cm}^{2}$ area defined by the marker in the image.

\section{RESULTS}

Figure 1, column 3, lists GSM, or grey scale median, for the selected wound regions of the five photographs obtained during the treatment period. Figure 1, column 4, shows histograms for the distribution of the percentages of number of pixels in each of 14 brightness amplitude intervals. The artificial colorization of pixels based on 14 brightness intervals is shown in Figure 1, column 5. The colors and brightness amplitudes for the 14 intervals are defined in Table 1. The percentages of total number 


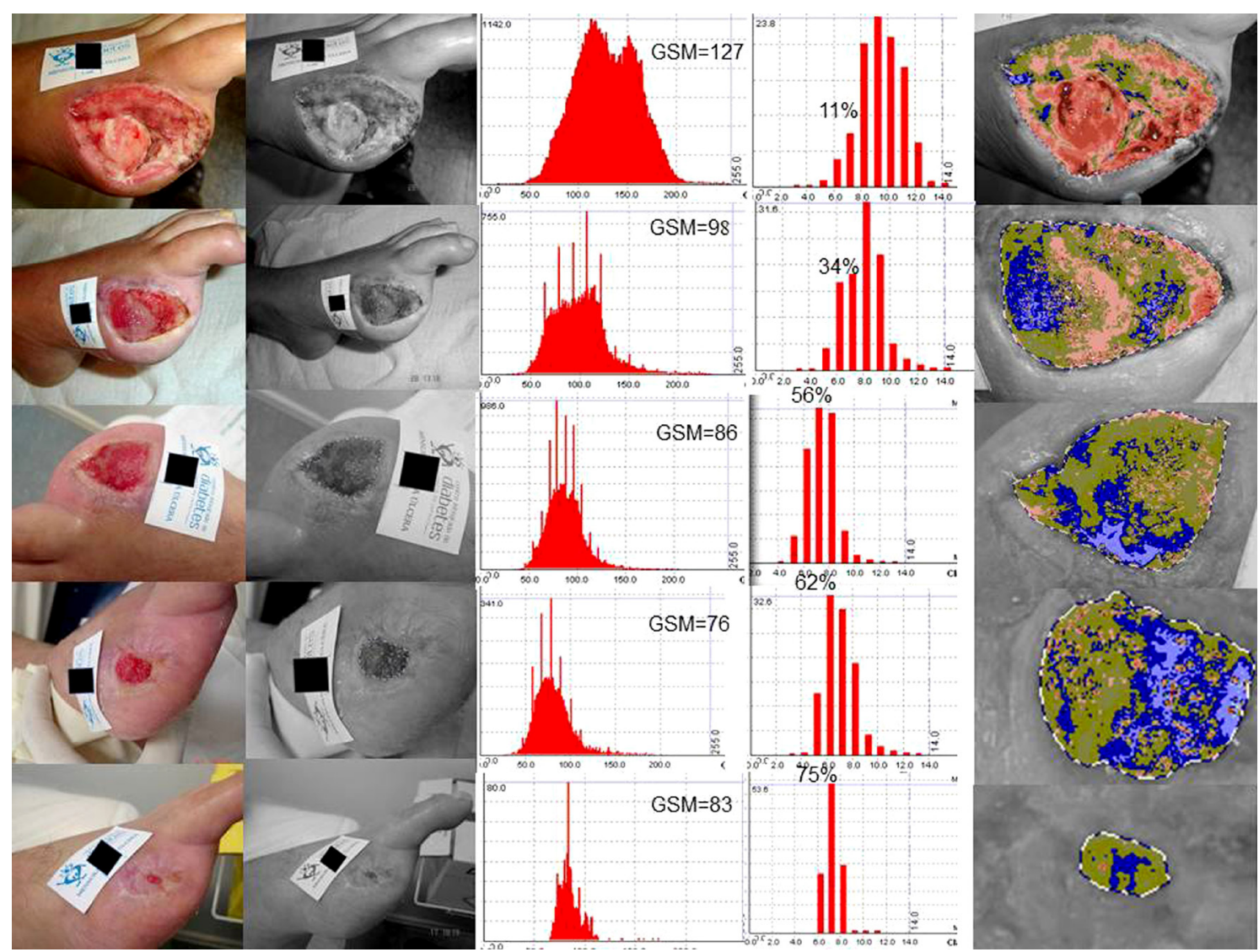

Figure 1. Photographic image tissue characterization ( $p$-IMTC) of ulcerated region of a diabetic foot after digital amputation and during medical treatment. Five photographic images taken over 3 months of treatment. Column 1: original image. Column 2: image converted to grey scale. Column 3: number of pixels distribution and grey scale median (GSM). Column 4: histogram of percentages of number of pixels within 14 brightness intervals. Explicit proportions are for granulation tissue with brighnesses in the 61 to 90 interval. Column 5: Artificial colorization of the wound image using 14 colors to represent brightness intervals. The relationships between colors and brightness intervals are given in Table 1.

of pixels in each of the grey scale brightness intervals are listed in Table 1 for the 5 images. The proportion of pixels within intervals from 61 to 90 increased steadily from $11 \%$ to $34 \%, 56 \%$ and $62 \%$, reaching $75 \%$ in the final image. The percentage of pixels with intensities within intervals from 112 to 196 reduced significantly from $67 \%$ to $29 \%, 8 \%$ and $6 \%$, reaching $1 \%$ in the final image. The 61-90- and 112-196 brightness intervals were identified as granulation of the wound and exposed bone respectively by an expert based on visual observation. The area of the lesion, the percentage of pixels representing granulation and the GSM are shown in Table 2 for the 5 images analyzed.

\section{DISCUSSION}

The p-IMTC technique identified alterations in image brightness of an ulcerated diabetic foot, as the wound healed under medical treatment following digital amputation. In particular, the proportion of granulation tissue increased as the wound healed. The granulation tissue was identified by an expert, based on visual observation, and associated to the 61 to 90 grey brightness interval of a grey scale image with 256 grey tones. The proportion of pixels with brightness within this 61-90 interval increased as the lesion healed. In contrast, the area corresponding to exposed bone tissue reduced as treatment progressed. Exposed bone tissue was associated with the 112 to 196 brightness interval; the proportion of pixels within this interval decreased during treatment. This study extended the application of the ultrasonographic USTC-CATUS technique to images in general, photographic images in this case. Analyses of aneurysms ${ }^{4}$, normal and transplanted kidneys $^{5,6}$, atheromas ${ }^{7-10}$, venous thrombosis ${ }^{11-13}$ and edema ${ }^{14}$ have thereby been extended to a potential application of photographic images to ulcerated wounds or peripheral injuries.

Physiologically, the human eye is, on average, capable of distinguishing only 16 of the 256 grey 
Table 1. Percentages of total number of pixels in each grey scale brightness interval for five photographic images of a diabetic foot. Intervals from 61 to 90 and from 112 to 196 were identified with granulation tissue and exposed bone respectively.

\begin{tabular}{|c|c|c|c|c|c|c|}
\hline \multirow{2}{*}{ Color } & \multirow{2}{*}{ Grey scale } & \multicolumn{5}{|c|}{ Percentage of total number of pixels within each interval (\%) } \\
\hline & & Image 1 & Image 2 & Image 3 & Image 4 & Image 5 \\
\hline & $0-4$ & 0.0 & 0.0 & 0.0 & 0.0 & 0.0 \\
\hline & $5-7$ & 0.0 & 0.0 & 0.0 & 0.0 & 0.0 \\
\hline & $8-26$ & 0.0 & 0.0 & 0.0 & 0.0 & 0.0 \\
\hline & $27-40$ & 0.0 & 0.1 & 0.0 & 0.4 & 0.0 \\
\hline & $41-60$ & 0.7 & 4.0 & 5.3 & 12.5 & 0.0 \\
\hline & $61-76$ & 3.7 & 16.4 & 23.5 & 32.6 & 21.1 \\
\hline & $77-90$ & 7.3 & 18.0 & 32.0 & 29.6 & 53.6 \\
\hline & $91-111$ & 20.1 & 31.6 & 31.0 & 18.7 & 24.1 \\
\hline & $112-132$ & 23.8 & 21.7 & 6.4 & 3.9 & 0.5 \\
\hline & $133-153$ & 20.9 & 4.9 & 1.3 & 1.6 & 0.5 \\
\hline & $154-174$ & 16.6 & 1.8 & 0.4 & 0.6 & 0.3 \\
\hline & $175-196$ & 6.1 & 0.9 & 0.1 & 0.3 & 0.0 \\
\hline & $197-210$ & 0.6 & 0.3 & 0.0 & 0.0 & 0.0 \\
\hline & $211-255$ & 0.4 & 0.3 & 0.0 & 0.0 & 0.0 \\
\hline
\end{tabular}

Table 2. Photographic image tissue characterization ( $p-I M T C$ ) of ulcerated lesion of a diabetic foot after digital amputation and during medical treatment. Five photographic images were obtained over approximately 3 months of treatment in chronological order from 1 to 5

\begin{tabular}{cccc}
\hline & Area of ulcer $\left(\mathbf{c m}^{\mathbf{2}}\right)$ & Area of granulation tissue (\%) & GSM \\
\hline Image 1 & 17.85 & 11 & 127 \\
Image 2 & 12.44 & 34 & 98 \\
Image 3 & 3.68 & 56 & 86 \\
Image 4 & 2.11 & 62 & 76 \\
Image 5 & 0.15 & 75 & 83 \\
\hline
\end{tabular}

GSM: Grey scale media.

scale tones commonly found in ultrasonographic images ${ }^{17}$. By processing and quantifying images using software designed to categorize and differentiate grey scale tones, visual perception can be enhanced and medical events and conditions can be monitored quantitatively. The artificial coloring technique produces images that direct an observer's attention to specific brightness intervals. Such intervals and their colors can be predefined based on earlier research, or selected by a specialist as it was the case of this "discovery phase" report. Both USTC and p-IMTC (CATUS and CATIM are the original Brazilian terms) techniques are dependent on the conditions and characteristics of the original images. The method described herein involved minimization of image variations by scale standardization. The images were rescaled based on arbitrary decisions of an experienced operator. The program employed redefined brightness values 0 and 200 of a 0 to 255 grey scale. We recommend that the operator does not attempt to optimize original images visually, particularly when using ultrasonography. This avoids introducing the effect of imperfect human vision into the process.
Tissue characterization is a precursor of virtual histology. In the case described herein, a specialist associated specific brightness intervals to granulation tissue or exposed bone tissue. The a priori intervals listed in Table 1 have been successfully used in past applications already described in the literature. In this specific case, the intervals used for granulation or exposed bone tissue did not require reformulation. Future analyses may confirm these intervals or may specify tissue intervals more precisely. Virtual histology is reached when the brightness intervals become adapted or redefined in response to histological data. As an example, Menezes et al. compared USTC or CATUS, of carotid artery plaques with histopathology findings ${ }^{7}$. Variability in histological sections and planes of ultrasound images were evaluated in such study. Virtual histology offers the advantage that it can be done in vivo without harming the patient. Certain images, however, cannot be considered histological, but supplementary, providing independent information. Therefore, p-IMTC/CATIM and its subgroup, USTC/CATUS may become an analytical tool in itself and not as a predictor of present day technologies. 


\section{CONCLUSIONS}

The technique of tissue characterization in images quantified information related to treatment of a diabetic foot. In particular, in addition to the size of the wound, grey scale median brightness and proportions of pixels within brightness intervals identified notable changes of granulation tissue or exposed bone as a result of treatment. Medical information has been extended by p-IMTC both qualitative and quantitatively. In the future, the p-IMTC technique could be used to analyze ulcers, wounds, lesions or other tissues, allowing quantification, characterization, and control of progression of a disease or treatment benefits. Serial assessments may indicate whether treatment needs to be adapted or modified. Following this report of a discovery, future research could improve imaging tissue characterization in daily medical practice.

\section{REFERENCES}

1. Evangelista SSM, Frankini AD, Vergara, EM, et al. VI fórum nacional da SBACV: o desafio do pé diabético. Cir Vasc Angiol. 1999;15:29-32.

2. De Luccia N. Doença vascular e diabetes. J Vasc Bras. 2003;2:49-60.

3. Miot HÁ, Mendaçolli TJ, Costa SV, Haddad GR, Abbade LPF. Úlceras crônicas dos membros inferiores: avaliação pela fotografia digital. Ver Assoc Med Bras. 2009;55:145-8. http://dx.doi. org/10.1590/S0104-42302009000200016

4. Salles-Cunha SX. Nota técnica: avaliação ultrassonográfica de aneurismas da aorta tratados com endopróteses. J Vasc Bras. 2012;11:150-3. http://dx.doi.org/10.1590/ S1677-54492012000200013

5. Valiente-Engelhorn AL, Engelhorn CA, Salles-Cunha SX, Ehlert R, Akiyoshi FK, Assad KW. Ultrasound tissue characterization of the normal kidney. Ultrasound Q. 2012; 28:275-80. http://dx.doi. org/10.1097/RUQ.0b013e318276f12b

6. Valiente-Engelhorn AL, Engelhorn CA, Salles-Cunha SX. Initial evaluation of virtual histology ultrasonographic techniques applied to a case of renal transplant. In: Congresso Anual da Society for Vascular Ultrasound (SVU); 2011; Chicago. E-published na Svunet.org (members only); 2011. Poster Abstract 412, p. 20.

7. Menezes FH, Silveira TC, Silveira SAF, Menezes ASC, Metze K, Salles-Cunha S. Histologia virtual baseada em ultrassonografia modo B de placas de ateroma na bifurcação carotídea. Resultados preliminares da comparação dos achados in vivo com histologia da placa obtida por endarterectomia de bifurcação carotídea. In: $39^{\circ}$ Congresso Brasileiro de Angiologia e Cirurgia Vascular; 2011; São Paulo. J Vasc Bras. 2011;10:Supl:32.

8. Marks NA, Ascher E, Hingorani AP, Shiferson A, Puggioni A. Grayscale median of the atherosclerotic plaque can predict success of lumen re-entry during subintimal femoral-popliteal angioplasty. J Vasc Surg. 2008;47:109-16. http://dx.doi.org/10.1016/j. jvs.2007.09.039

9. Biasi G, Froio A, Diethrich EB, et al. Carotid plaque echolucency increases the risk of stroke in carotid stenting. Circulation. 2004;110:756-62. http://dx.doi.org/10.1161/01. CIR.0000138103.91187.E3

10. Lal BK, Hobson RW 2nd, Pappas PJ, et al. Pixel distribution analysis of B-mode ultrasound scan images predicts histologic features of atherosclerotic carotid plaques. J Vasc Surg. 2002;35:1210-7. http://dx.doi.org/10.1067/mva.2002.122888
11. Barros FL, Sandri JL, Prezotti BB, et al. Embolia pulmonar: uma rara associação com trombo flutuante da veia basílica identificada pelo ultrassom. Rev Bras Ecocardiogr Imagem Cardiovasc. 2011;24: 89-92.

12. Cassou-Birckholz MF, Engelhorn CA, Salles-Cunha SX, et al. Assessment of deep venous thrombosis by grayscale median analysis of ultrasound images. Ultrasound Q. 2011;27:55-61. http://dx.doi.org/10.1097/RUQ.0b013e31820e157d

13. Menezes FH, Silveira SAF, Salles-Cunha SX. Pixel characterization for development of ultrasound-based virtual histology of deep venous thrombosis. In: Congresso Anual da Society for Vascular Ultrasound (SVU); 2011; Chicago. E-published na Svunet.org (members only); 2011. Poster Abstract 109, p. 3.

14. Salles-Cunha SX, Silveira AFS, Menezes FH. Ultrasound virtual histology to grade treatment of lower extremity lymphedema. In: Congresso Annual da Society of Vascular Ultrasound (SVU); 2012.

15. Layland J, Wilson AM, Lim I, Whitbourn RJ. Virtual histology: a window to the heart of atherosclerosis. Heart Lung Circ. 2011;20:615-21. http://dx.doi.org/10.1016/j.hlc.2010.12.002

16. Deftereos S, Giannopoulos G, Kossyvakis C, Pyrgakis V. Virtual histology. Review Article. Hellenic J Cardiol. 2010;51:235-44.

17. Beach KW, Paun M, Primozich JF. Principles and instruments of diagnostic ultrasound and doppler ultrasound. In: Aburahma AF, Bergan JJ, editors. Noninvasive Vascular Diagnosis: a practical guide to therapy. 2nd ed. London: Springer-Verlag; 2007. p. 27. http://dx.doi.org/10.1007/978-1-84628-450-2_3

Correspondence
Sergio Xavier Salles Cunha
Rua Ernesto Zwarg, 215 - Satélite
CEP 11740-000 - Itanhaém (SP), Brazil.
E-mail: sergioxsc@yahoo.com

Author's information

VHHP, EMCF, FTAS, TFAS, RASB are medical students at Universidade Estadual de Ciências da Saúde de Alagoas (UNCISAL), Maceió, AL, Brazil.

${ }^{2} \mathrm{SXSC}$ is consultant at Noninvasive Vascular Diagnostic Techniques, Itanhaém, SP, Brazil.

${ }^{3} \mathrm{KAMB}$ is medical student at Universidade Federal de Alagoas, Maceió, AL, Brazil

${ }^{4} \mathrm{SC}$ is lato sensu degree in Vascular and Endovascular Surgery, Sociedade Brasileira de Angiologia e Cirurgia Vascular (SBACV) Member, CBC and SBACV, Vascular surgeon, Vascular Surgery Service, Hospital Federal dos Servidores do Estado, Rio de Janeiro, RJ, Brazil, and Hospital Municipal Miguel Couto, Rio de Janeiro, RJ, Brazil.

Author's contributions

Conception and design: VHHP, EMCF, FTAS, TFAS, KAMB, SXSC Analysis and interpretation: VHHP, KAMB, SXSC, JSC Data collection: VHHP, EMCF, FTAS, TFAS, KAMB, RASB, JSC Writing the article: VHHP, EMCF, FTAS, TFAS, SXSC Critical revision of the article: VHHP, EMCF, FTAS, TFAS, SXSC, KAMB, RASB, JSC

Final approval of the article*: VHHP, EMCF, FTAS, TFAS, SXSC, KAMB, RASB, JSC Statistical analysis: SXSC, KAMB, RASB, JSC Overall responsibility: SXSC Obtained funding: None.

*All authors should have read and approved of the final version of the article submitted to I Vasc Bras. 